\title{
Integrator Scenario: The Emergence of a Curriculum Reconfiguration Proposal
}

\author{
Sara Souza Pimenta \\ Brazil \\ Thiago Santos Guimarães \\ Nataélia Alves da Silva \\ Brazil \\ Andrei Steveen Moreno Rodríguez \\ Brazil \\ Elisa Prestes Massena \\ Brazil \\ Brazil
}

The curriculum can be understood as one of the matrixes in which varied forms of social production are personalized, however, a large part of school curricula has disfavored the social classes most vulnerable. To overcome this, some proposals for curricular reconfiguration emerged in order to promote contextualized and intrinsic of the Science Teaching. The objective of this article is to present the emergency process and the rationale for the proposal of curricular reconfiguration Integrator Scenario built in the context of the GPeCFEC. This proposal integrates sets of elements that enable the study of themes, situations and real problems of social relevance. Thus, a documental analysis was carried out based on a bibliographic survey of monografies and master's thesis developed respectively within the scope of the Degree in Chemistry and the Graduate Program in Science Education, both from the University. The results of this study show that the Integrator Scenario gives work pedagogical, critical and social perspective beyond the concept learning. This proposal can also contribute to the integration of school, academic and social spaces, in addition to encouraging the different performance of future teachers and the continuing education of their participants.

Keywords: Curriculum Reconfiguration; Critical curriculum; Science teaching.

\section{Introduction}

The advancement of curriculum theories has contributed to answer factors about teaching and learning - the main concern of the traditional curriculum line. Moreover, knowing that the curriculum is the matrix in which various forms of social production are customized, its study allows us to understand how culture influences the processes of education, teaching and learning, limiting or allowing the rise of individuals in society, and these issues are deepened in the lines of the critical and post-critical curriculum (Sacristán, 1998; Silva, 1995; 2001).

Faced with social demands and with the advancement of curricular theories corroborating the change in school curricula, several Proposals for Curricular Reconfiguration were developed to overcome the contentist focus of the traditional curriculum and promote a science teaching that is contextualized and intrinsic to reality. 
Among them, it is possible to mention the proposals Science, Technology and Society (Ratcliffe, Grace, 2003), Science, Technology, Society and Environment (Pedretti, Nazir, 2011), Freirean Thematic Approach (Delizoicov et al., 2011) and Study Situation (Maldaner, 2007). These proposals are different suggestions of how the curriculum at school level can be organized based on a scientific, social theme, or the experience of the students, which can facilitate the teaching of content.

In the context of a Santa Cruz State University (UESC), between 2009 and 2010, the Study Situation began to be developed in the Institutional Program of Teaching Initiation Scholarships (PIBID) for Chemistry by the first members, who would later constitute the Group for Research in Curriculum and Teacher Training in Science (GPeCFEC) ${ }^{1}$. In 2012, this research group signed a partnership with the Interdepartmental Research Group on Science Education of the Regional University of the Northwest of the State of Rio Grande do Sul (Gípec-Unijuí) through the research project approved in Edital CNPq Universal 14/2011 (Massena \& Brito, 2015; Sousa, 2018), which aimed to develop and investigate the proposed Study Situation.

The Study Situation is based on a "concrete situation, from the students' experience, conceptually rich for several fields of science, in order to allow interdisciplinary analysis and establish transdisciplinary interconnections" (Maldaner, 2007, p. 248). Methodologically, this proposal of curricular reconfiguration is planned and developed by a collective of teachers, which includes professors of Higher Education, teachers of Basic Education, undergraduate and graduate students. This collective has the function of "electing the most representative scientific concepts and their level of significance, in order to provide a fuller understanding of the situation in focus" (Pansera-de-Araújo et al., 2007, p. 170). For this, broad themes are chosen based on transversal themes. Thus, according to Maldaner (2007), the concepts can be worked on by transdisciplinary strand, transiting within the area of Nature Sciences, between the disciplines of Chemistry, Physics, and Biology.

Maldaner and Zanon (2006) indicated that, while new Study Situations would be produced, other references and different forms of planning could emerge. In this perspective, several proposals were elaborated in the context of GPeCFEC. Even Vieira (2017), Vieira, Fernandes, Massena, Maldaner (2018) point out a significant production of works in Annals of events and articles about this proposal, coming from the Northeast region.

The Study Situation is mainly concerned with the cognitive factors of learning and, its main reconfiguration factor is focused on working the scientific concept in an interdisciplinary way. As a result, it has been perceived that social demands are not met in this proposal, which has made its implementation difficult. Thus, some researchers and students who develop or have developed the proposal of the Study Situation report the need for several adaptations made in order to implement such reconfiguration in

\footnotetext{
1 GPeCFEC develops initial and continuing teacher training processes within the scope of the Chemistry Degree course at UESC and in schools in the southern region of Bahia. More information about the work and activities of GPeCFEC can be found at https://groupsdepesquisa.wixsite.com/gpecfec.
} 
schools in the Northeast region, in order to consider the particularities of the schools and the teaching modalities in which they have been working.

For example, Pimenta (2016) has developed a proposal for curriculum reconfiguration addressing ethnic-racial issues from the theme of curly hair in a technical course on Biofuels. The proposal of Silva (2017) promotes the debate about water pollution of the Almada River from the contents of Nature Sciences, encouraging the construction of the social being of participating students. Almeida (2017) discusses the problem of garbage management in rural areas in the context of rural education. Silva (2019) developed his proposal on the theme of food sovereignty in an Integrated Center of a Landless Rural Workers Movement (MST).

This continuous production of curricular proposals, in the context of GPeCFEC, became an act of investigation of the actions themselves, in an attempt to improve them in a research-action movement (Tripp, 2005; Zubbert-Skerrtitt, 2005). And, as for the characteristics of this proposal regarding its development in schools in a region of differentiated context such as the Brazilian Northeast, some questions were raised such as: "What characterizes this proposal?", "How and who should participate in the construction of the proposal?", "What are the criteria required in the choice of themes?

Therefore, the objective of this article is to present the emergency process and the rationale for the proposal of curricular reconfiguration Integrating Scenario built in the context of GPeCFEC. This proposal integrates sets of elements that enable the study of themes, situations, and real problems of social relevance.

\section{Curriculum Reconfiguration}

The curriculum is a selection of culture because its structure, organization, and the knowledge taught at school are choices of a group of people. This means that it is not the whole culture that exists, but a summary of it that can serve for socialization and reproduction, even if it does not aim at it in a prescribed way. Culture, therefore, is built and reconstructed according to the particular conditions in the process of schooling, teaching, learning, and can only be learned in the practical areas that make up the curricular system (Sacristán, 1998).

For Sacristán (2000, p. 101), the curriculum must be understood as a system because it "creates around itself diverse fields of action in which multiple agents and forces express themselves in its configuration, focusing on different aspects". This means that the activities that allow the curriculum's functionality are only possible when people and groups of people appropriate and carry out such activities. The curricular system is then maintained in a non-linear, dynamic process strongly related to historical factors.

In this curricular system, the creation, management and maintenance of the curriculum phases are performed by the internal and external context. The internal context refers to the school's conditioning, to what the school's agents select and organize for the curriculum. The external context influences all the internal contexts of the practical areas of the curriculum, and political, social, economic, cultural, other 
relations are intrinsic to it (Sacristán, 1998).

Knowing that the external context can strongly influence the school curriculum, a two-way street is established through it, because, in another direction, society can be efficiently dominated through education and culture, which will act for the maintenance and exploration of hegemonic relations in the social environment (Apple, 1989).

Thus, controlling cultural life and its consequences is controlling the daily practice of individuals, where the role of institutions in the system of our society is concentrated, among them the school. The act of going to school is among the most important daily practices in families of any social level, therefore, education is one of the most massive means of domination that dominant groups can appropriate (Apple, 2006). In this sense, the school controls cultural life through the type and form of knowledge it teaches.

Although the curriculum is a complex set of diverse elements, it can be understood that it is configured from its formal structures and social functions managed by social, political, and economic factors. The configurations that school curricula have taken tend to present traditional forms that arouse conteudism and distance between the school and the real life of the students. Thus, it is considered that this structure can be reconfigured to achieve a curriculum that allows the transformation of reality. In other words, through the construction of new proposals for curricular reconfiguration.

As the configuration of the curriculum is sometimes still understood as a list of contents, then some refer to the Curriculum Reconfiguration as "a process characterized by variations in the selection of the contents taught, based on contextualization and the search for the construction of senses for learning" (Mesquita, 2019). However, varying the content is a simplistic way to change the curriculum, this would only be a reorganization in which the order of the contents selected by the selective tradition (Apple, 2006) occupies different sequences since they are the same contents worked on.

Others associate this term "with daily productions of school curricula as a place for reconfiguration of prescribed curricula" (Campos \& Reis, 2019). However, the daily productions of schools can only be considered impulses of curricular reconfiguration if they are systematized in the level of activities corresponding to the organizational practices in structure and internal organization of the school (Sacristán, 1998).

According to the Magno Dicionário Brasileiro da Língua Portuguesa (Maia, 1995), the word configuration denotes "the shape of a body" or "cultural elements that are found in a certain area at a certain time", therefore, Curricular Reconfiguration is understood as the act of reconfiguring the current curriculum of a country, school or discipline, giving it a new shape or bringing new cultural elements.

In this article, we consider the curricular reconfiguration according to the levels of the curriculum defined by Sacristán $(1998,2000)$, which are: a) Organized Curriculum - which corresponds to the organizational practices in a structure and internal organization of the school that characterizes its project; b) Curriculum in action - that in which the actual practice is effective. It is there that the pedagogical action is concretized creating meaning and interaction between knowledge and culture. This 
level of curriculum is effective in the classroom because in it the learning tasks that can adopt a psychological and social focus are performed; and c) Evaluated Curriculum which is the most direct and immediate form of the curriculum to the student and is differentiated from other phases by its evaluation characteristics. In this phase, a new organization of the subjects, activities, and tasks is foreseen, towards a more politically engaged attitude of the teachers.

But changing the curriculum should not be associated only at a structural level, an effort should be made so that ideological and hegemonic influences are discovered and modified or at least questioned so that the school's curriculum remains in reconfiguration. For this, it is necessary to change the state of neutrality in education and in the school, characterized by the act of teachers and education professionals not dealing with problems relevant to society and to the students, which helps to maintain hegemonic relations sustained by common sense (Apple, 2006).

In this sense, Apple (2006, p. 45) guides the expansion of such a study beyond the walls of the educational institution and its curriculum, centered on the theory of social justice, contributing "to the benefit of those who are at a disadvantage. The reason is that if educational actions do not reach people's cultural life, little or nothing advances the attempts of changes in the school environment and, those subjects in social disadvantage will still remain at a disadvantage (Apple, 1989).

Thus, the proposal of curriculum reconfiguration may create conditions for the institution to discuss issues of social and scientific relevance as well as allow the emergence of new curricula attuned to the demands of society through the study of topics (Simonneaux, 2014).

\section{Researches and actions}

In order to present the emergency process in which the proposed curriculum reconfiguration Integrating Scenario was identified, a bibliographic survey and documentary analysis of Course Conclusion Papers (CCP) and thesis developed within the UESC was conducted.

For the documentary analysis, the thesis was found on the page of the Graduate Program of Education in Sciences of UESC, through the search of the term "Study Situation" in the title or abstract of the text. Since the CCP generated in UESC's undergraduate courses are not available online, the students who produced their CCP on Situation of Study were contacted and requested the text.

After the classification of these researches, the reading, and analysis of the texts was carried out, with greater attention to the sections of methodology, results and discussion, and final considerations, because in these sections the authors describe the research in more detail and express their perceptions and conceptions about the reconfiguration proposals developed or analyzed in their researches. Then, the interpretative analysis of the most frequent terms in the texts, such as triad, collective work, broad themes, experience, and pedagogical concept, was carried out, and these terms, in this article, 
are reinterpreted under the conception of the authors of the identified researches and based on arguments supported by the adopted theories.

As Guba and Lincoln (1981 cited in Lüdke \& André, 1986) point out, the documentary analysis comprises several advantages, such as stability (referring to both time and the various re-reading that can be done by different people) and the great amount of information it contains. Besides, documents are always created in a certain context, so symbols of that context will be present in their writing. Thus, it was chosen to analyze the researches developed under the condition that the authors have been participants of GPeCFEC or guided by UESC research professors who investigate the Study Situation, in order to characterize the emerging proposal in this scenario.

Twenty-one (21) researches were identified, nine (9) are thesis and twelve (12) are CCP. In Figure 1, these researches are presented through information about the author, title, character, year of defense of the research, and the corresponding objective to approach the proposal of reconfiguration that each research adopted.

\begin{tabular}{|l|l|c|c|l|}
\hline Author & Title & Character & $\begin{array}{l}\text { Year of } \\
\text { defense }\end{array}$ & Objective \\
\hline $\begin{array}{l}\text { Amaral, } \\
\text { G. }\end{array}$ & $\begin{array}{l}\text { Study Situation: a new curricular } \\
\text { Approach in the technical course in } \\
\text { Biotechnology }\end{array}$ & CCP & 2013 & $\begin{array}{l}\text { Elaboration and } \\
\text { implementation } \\
\text { of the proposal }\end{array}$ \\
\hline $\begin{array}{l}\text { Fernandes } \\
\text { F. G. }\end{array}$ & $\begin{array}{l}\text { Contributions from the Study Status } \\
\text { to the Initial Formation of Chemistry } \\
\text { Teachers at Santa Cruz State } \\
\text { University }\end{array}$ & CCP & 2014 & $\begin{array}{l}\text { Preparation of a } \\
\text { proposal }\end{array}$ \\
\hline $\begin{array}{l}\text { Pinto, J. G. } \\
\text { R. }\end{array}$ & $\begin{array}{l}\text { Study Situation: Self-medication, } \\
\text { necessary harm? A curricular } \\
\text { approach in a Technical course }\end{array}$ & CCP & 2015 & $\begin{array}{l}\text { Elaboration and } \\
\text { implementation } \\
\text { of the proposal }\end{array}$ \\
\hline $\begin{array}{l}\text { Bomfim, } \\
\text { R. C. }\end{array}$ & $\begin{array}{l}\text { Self-medication as a Study Situation } \\
\text { for the Teaching of Chemistry }\end{array}$ & CCP & 2016 & $\begin{array}{l}\text { Elaboration and } \\
\text { implementation } \\
\text { of the proposal }\end{array}$ \\
\hline $\begin{array}{l}\text { Pimenta, } \\
\text { S. S. }\end{array}$ & $\begin{array}{l}\text { Knowing Curly Hair Chemistry: } \\
\text { A study situation in the technical } \\
\text { course }\end{array}$ & CCP & 2016 & $\begin{array}{l}\text { Elaboration and } \\
\text { implementation } \\
\text { of the proposal }\end{array}$ \\
\hline $\begin{array}{l}\text { Reis, C. M. } \\
\text { R. }\end{array}$ & $\begin{array}{l}\text { Youth and Adult Education: The Study } \\
\text { Situation as a possibility to rethink the } \\
\text { curriculum }\end{array}$ & CCP & 2016 & $\begin{array}{l}\text { Elaboration and } \\
\text { implementation } \\
\text { of the proposal }\end{array}$ \\
\hline Santos, C. & $\begin{array}{l}\text { Possible Contributions of the } \\
\text { Curriculum Proposal Study Status } \\
\text { in the Youth and Adult Education } \\
\text { Curriculum }\end{array}$ & CCP & 2016 & $\begin{array}{l}\text { Curriculum } \\
\text { analysis }\end{array}$ \\
\hline $\begin{array}{l}\text { Guimarães, of Jorge Amado's literature in } \\
\text { science teaching: A possibility from a } \\
\text { Study Situation }\end{array}$ & CCP & $\begin{array}{l}\text { Elaboration and } \\
\text { implementation } \\
\text { of the proposal }\end{array}$ \\
\hline
\end{tabular}

Figure 1. Dissertations and PPCs developed in the context of the Group for Research in Curriculum and Teacher Training in Science Teaching (GPeCFEC) (to be continued)

Source: Research data, 2019. 


\begin{tabular}{|c|c|c|c|c|}
\hline Autor & Título & Caráter & $\begin{array}{l}\text { Ano de } \\
\text { defesa }\end{array}$ & Objetivo \\
\hline $\begin{array}{l}\text { Sampaio, } \\
\text { T. S. }\end{array}$ & $\begin{array}{l}\text { Youth and Adult Education: a } \\
\text { continuing education activity based } \\
\text { on the assumptions of the Study } \\
\text { Situation }\end{array}$ & ССР & 2017 & $\begin{array}{l}\text { Teacher training } \\
\text { course }\end{array}$ \\
\hline Silva, U. K. & $\begin{array}{l}\text { Almada River: a Study Situation as a } \\
\text { Proposal for Science Teaching }\end{array}$ & ССР & 2017 & $\begin{array}{l}\text { Elaboration and } \\
\text { implementation } \\
\text { of the proposal }\end{array}$ \\
\hline $\begin{array}{l}\text { Pereira, D. } \\
\text { B. }\end{array}$ & $\begin{array}{l}\text { Food and gastritis: Possible } \\
\text { Contributions from the Study } \\
\text { Situation to the PROEJA }\end{array}$ & ССР & 2017 & $\begin{array}{l}\text { Curriculum } \\
\text { analysis }\end{array}$ \\
\hline $\begin{array}{l}\text { Silva, L. N. } \\
\text { C. }\end{array}$ & $\begin{array}{l}\text { Study situation and investigative } \\
\text { experimentation: possible } \\
\text { contributions to the learning of } \\
\text { chemical concepts }\end{array}$ & $\mathrm{CCP}$ & 2018 & $\begin{array}{l}\text { Elaboration and } \\
\text { implementation } \\
\text { of the proposal }\end{array}$ \\
\hline $\begin{array}{l}\text { Resende, R. } \\
\text { C. S. }\end{array}$ & $\begin{array}{l}\text { Development of study situation as a } \\
\text { facilitator of the process of teaching } \\
\text { and learning nature sciences in the } \\
\text { 9th grade of elementary school }\end{array}$ & Thesis & 2015 & $\begin{array}{l}\text { Elaboration and } \\
\text { implementation } \\
\text { of the proposal }\end{array}$ \\
\hline Jesus, D. & $\begin{array}{l}\text { Our daily coffee: investigating the } \\
\text { influence of a study situation on the } \\
\text { process of teaching and learning } \\
\text { nature sciences in high school }\end{array}$ & Thesis & 2016 & $\begin{array}{l}\text { Elaboration and } \\
\text { implementation } \\
\text { of the proposal }\end{array}$ \\
\hline $\begin{array}{l}\text { Almeida, C. } \\
\text { L. S }\end{array}$ & $\begin{array}{l}\text { Study situation in teacher training } \\
\text { in rural schools at the Coaraci-BA }\end{array}$ & Thesis & 2017 & $\begin{array}{l}\text { Teacher training } \\
\text { course }\end{array}$ \\
\hline $\begin{array}{l}\text { Vieira, L. B. } \\
\text { G. }\end{array}$ & $\begin{array}{l}\text { Study Situation: understandings of } \\
\text { science teaching teacher trainers }\end{array}$ & Thesis & 2017 & $\begin{array}{l}\text { Bibliographic } \\
\text { survey }\end{array}$ \\
\hline $\begin{array}{l}\text { Alves, W. } \\
\text { F. S. }\end{array}$ & $\begin{array}{l}\text { Teaching Knowledge in the Initial } \\
\text { Formation of Science Teachers: } \\
\text { (re)thinking educational practices } \\
\text { through the Ilhéus Study Situation }\end{array}$ & Thesis & 2018 & $\begin{array}{l}\text { Preparation of a } \\
\text { proposal }\end{array}$ \\
\hline $\begin{array}{l}\text { Peixoto, C. } \\
\text { A. S. }\end{array}$ & $\begin{array}{l}\text { Study Situation in Technical } \\
\text { Professional Education: distances } \\
\text { and approaches }\end{array}$ & Thesis & 2018 & $\begin{array}{l}\text { Teacher training } \\
\text { course }\end{array}$ \\
\hline
\end{tabular}

Figure 1. Dissertations and PPCs developed in the context of the Group for Research in Curriculum and Teacher Training in Science Teaching (GPeCFEC) (to be continued)

Source: Research data, 2019. 


\begin{tabular}{|l|l|c|c|l|}
\hline Author & Title & Character & $\begin{array}{c}\text { Year of } \\
\text { defense }\end{array}$ & Objective \\
\hline $\begin{array}{l}\text { Alves, W. } \\
\text { F. S. }\end{array}$ & $\begin{array}{l}\text { Teaching Knowledge in the Initial } \\
\text { Formation of Science Teachers: } \\
\text { (re)thinking educational practices } \\
\text { through the Ilhéus Study Situation }\end{array}$ & Thesis & 2018 & $\begin{array}{l}\text { Preparation of a } \\
\text { proposal }\end{array}$ \\
\hline $\begin{array}{l}\text { Peixoto, C. } \\
\text { A. S. }\end{array}$ & $\begin{array}{l}\text { Study Situation in Technical } \\
\text { Professional Education: distances and } \\
\text { approaches }\end{array}$ & Thesis & 2018 & $\begin{array}{l}\text { Teacher training } \\
\text { course }\end{array}$ \\
\hline Sousa, P. S. & $\begin{array}{l}\text { Professional development of } \\
\text { teachers in the context of curricular } \\
\text { reconfiguration by the Study } \\
\text { Situation }\end{array}$ & Thesis & 2018 & $\begin{array}{l}\text { Preparation of a } \\
\text { proposal }\end{array}$ \\
\hline $\begin{array}{l}\text { Bomfim, R. } \\
\text { C. }\end{array}$ & $\begin{array}{l}\text { Collaborative work on the university- } \\
\text { school interface: (re)thinking the } \\
\text { curriculum through the Study } \\
\text { Situation }\end{array}$ & Thesis & 2019 & $\begin{array}{l}\text { Elaboration and } \\
\text { implementation } \\
\text { of the proposal }\end{array}$ \\
\hline Silva, F. N. & $\begin{array}{l}\text { The Study Situation in MST Teacher } \\
\text { Training: Dialogues with Henri A. } \\
\text { Giroux }\end{array}$ & Thesis & 2019 & $\begin{array}{l}\text { Teacher training } \\
\text { course }\end{array}$ \\
\hline
\end{tabular}

Figure 1. Dissertations and PPCs developed in the context of the Group for Research in Curriculum and Teacher Training in Science Teaching (GPeCFEC) (continuation)

Source: Research data, 2019.

In this first analysis, it was noticed that the researches present groups of similar objectives. Therefore, these objectives were classified into:

Curriculum analysis (two researches) - Some of the researches indicated in Figure 1 reserve a section of their texts to deal with the curriculum of the teaching modality in which they developed the proposals (Amaral, 2013; Reis, 2016; Bomfim, 2017). But, specifically, the researches of Santos (2016) and Pereira (2017) were dedicated to curriculum analysis. They were developed in the modalities of Youth and Adult Education (EJA) and the National Program for the Integration of Professional Education with Basic Education (PROEJA), respectively. They tried to identify possible contributions and limitations of a proposal of curricular reconfiguration in these modalities of teaching.

Teacher training course (four researches) — The training courses are generally requested by the schools and elaborated by the GPeCFEC, considering the demands of the school. According to the objectives of these researches, when the courses are implemented, they seek to investigate how the proposal can contribute to the training of these teachers and how they can enhance the development of the proposal from their context. The training courses and mini-courses are elaborated with a representative 
structure of a proposal of curricular reconfiguration, thus, the participants experience and at the same time build the proposal.

Preparation of a proposal (three researches) - These researches intended to analyze the relations maintained between the participants during the elaboration of the proposal.

Elaboration and implementation of the proposal (eleven researches) - These studies reflected on the context of the school and aimed to propitiate the learning of the students about certain concepts and contents of Sciences. They were also concerned with discussing the context of the elaboration, such as the choice of theme and the role of the participants (teachers of Basic Education, undergraduates, masters and university professors).

Bibliographic Survey (one survey) - Vieira (2017) survey indicates the regions with the highest production of Study Situation and discusses the conceptions of teacher trainers who developed this proposal.

Chronologically, it is possible to perceive an advance in the appropriation of the reconfiguration proposals in face of the needs of the contexts in which they are built and implemented, which is related to the action-research movement.

GPeCFEC has researched curriculum and teacher training in science teaching with a focus on curricular reconfiguration. With each research, an action is developed (training courses, elaboration, and implementation of a curricular proposal), promoting, consequently, the reflection on what and how the action was carried out, be it of the individual or the group in a collaborative, critical and self-critical investigation. In this case, the problem arises and the participants approach it in order to solve it.

This cycle is given in the process of oscillation between investigating the practice and acting on it (Tripp, 2005). It is understood here that action-research is the point of scientific study that refers to anomalies and crisis in normal science (Kuhn, 1996), because it is in this state that doubts are installed and the search for answers becomes inevitable, the flaws of the studied theory are questioned and actions are executed until the questions are answered. Therefore, to develop action-research means to remain in a state of crisis, of questioning, and this is clearly a political, critical, and hegemonic resistance position. Thus, it is also understood that the attempt to solve this problem does not mean research with a linear method of resolution, but rather a process of cyclical sets that form a spiral, as shown in Figure 2 below:
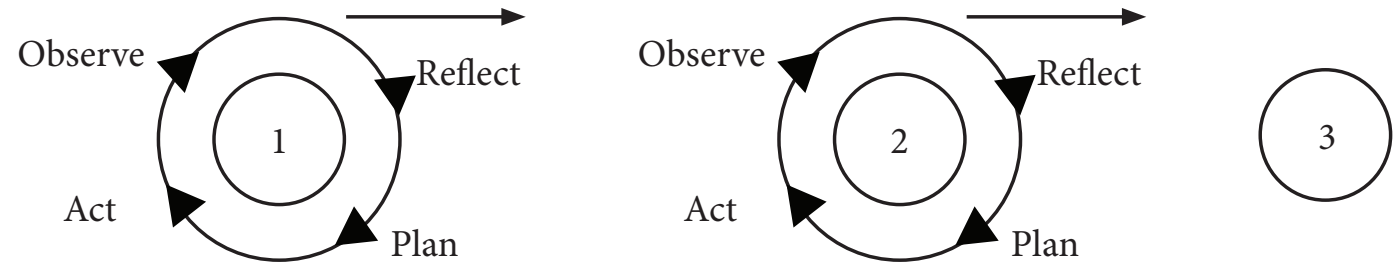

Figure 2. Cyclic spiral process of action research

Source: Zubert-Skerrtitt, p. 20, 2001, adaptation and our translation. 
It is considered that the action-research that occurred in GPeCFEC resembles the cyclical spiral model (Zubbert-Skerrtitt, 2005), because action-research, in purely cyclical models (Tripp, 2005), can pass the wrong idea of an endless research in which problems, ideas and actions are repeated. Thus, the action is the result of research and the next research is the result of the action, considering that academic research is completed, or delivered, because there is a need to meet academic demand. Thus, when research is delivered, new questions are raised so that a new investigation, new planning, and new actions are carried out. In order for such research process to remain in cycle, the participating subjects must be involved in all stages of the research process in a symmetrical relationship.

Although the other researches have shown advances not only theoretically, but also in school practice, from the Vieira (2017) research, an important process of the actionresearch spiral (Zubert-Skerrtitt, 2005) begins within the research group. The author raises two main questions that suggest the revision of the curricular reconfiguration proposal developed at GPeCFEC, linked to the professional development of teachers involved in the process of building and implementing the proposals.

Thus, Alves (2018) and Sousa (2018), in continuity with the Vieira (2017) research, sought to analyze what were the contributions of the proposed curriculum reconfiguration to the constitution of teachers' knowledge in the initial training and teachers of Basic Education of Physics and Chemistry, and how the relationship established between these subjects influenced their processes of permanent training and professional development. Alves (2018) and Sousa (2018), agree that there is a need to create investigative communities in which Basic Education teachers act more effectively.

The second issue pointed out by Vieira (2017) is the investigation of the cultural dimension of the proposed curricular reconfiguration. In this, Bomfim (2019) and Silva (2019) began in their researches the study of authors of critical theory to study the cultural and social character of the proposals developed.

These movements of continuity of research point to action-research as a practice of change and progression of ideas, both in theory and in more critical practice. Thus, directing to a more complex understanding of social and educational practice so that they know how to change it (Kemmis, 2009).

In view of the process of studying one's own actions that the research group in question ended up experiencing, it is possible to reflect on three types of action research (Zubert-Skerrtitt, 2005): Technical - aims to improve the practice; Practical - aims to understand the whole process by which the teacher will go through his professional development; Empirical - besides the improvement and understanding of the practice, it also aims the transformation and change within the limits of reality, the empowerment, and self-confidence of the participants about their capacity to create theories based on their own practices.

In these three types of research-action, all actions are taken collaboratively within a group or research community in a peer-to-peer relationship. In this, action- 
research is configured by "research that promotes collectivity and self-reflection in which participants are committed to improving (1) the rationality and justice of their own social or educational practices; (2) the participants' understanding of these practices" (Kemmis \& Mctaggart, 1988 quoted in Altrichter, et al. p. 125, 2002, our translation).

Thus, action-research is emancipatory when it seeks to change existing conditions, the reality where one works and even the system, in order to overcome the elements that impede improvement action, considering the potentialities and limitations of the context under investigation. In this sense, Winter (2005) reinforces that action-research is a way of investigating and analyzing professional practice and experience in continuous movement.

\section{Integrating elements in scenario creation}

In this action-research process, characteristics were perceived in the proposals elaborated in the context of GPeCFEC /UESC that are distant or divergent from the Study Situation, being perceived as the emergence of a new proposal of curricular reconfiguration. Thus, during the process of reading and re-reading the CCP and thesis categories were constructed that can help in the characterization of this proposal, which is named Integrating Scenario and represented in Figure 3 below, by means of an organogram that synthesizes its proposed structure in this research.

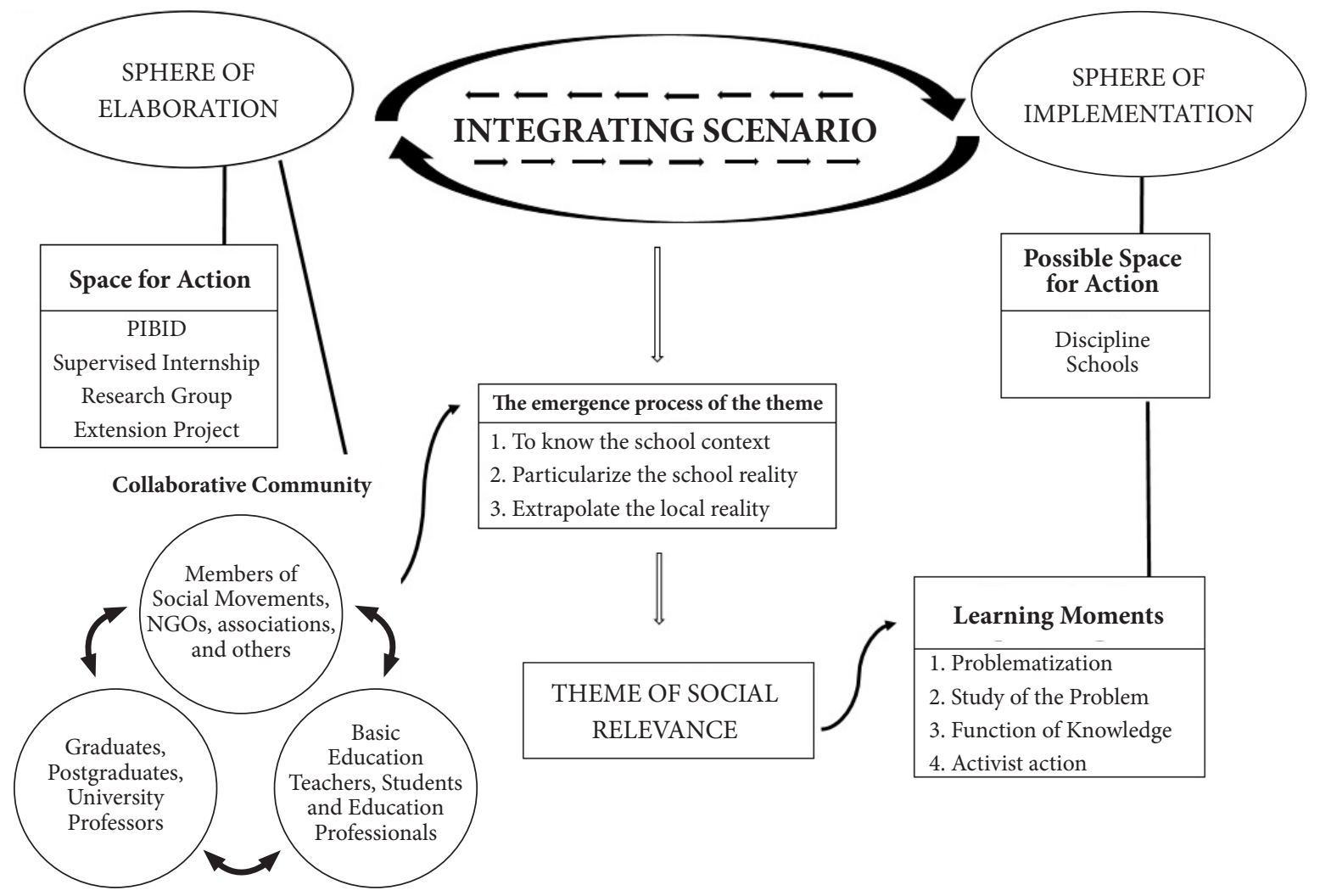

Figure 3. Structure of the Curriculum Proposal Integrator Scenario 
A scenario is a set of elements that forms a "circumstance, situation or condition" (Borba, 2004, p. 261). In turn, the word "integrate" gives rise to the act of joining elements and parts, "becoming an integral part" to "complete oneself" (Ximenes, 2000, p. 538). In this sense, the Integrating Scenario is a proposal of curricular reconfiguration that integrates sets of elements that make possible the study of themes, situations and real problems of social relevance. For the construction of these proposals two sets of elements are contemplated, the Elaboration Sphere and the Implementation Sphere.

For the Elaboration Sphere, the following emergent categories can be considered: Elaboration space of the proposal; Elaborators ( $\mathrm{G}$ - Graduates, BET - Basic Education Teacher, UT University Teacher, PG - Post-Graduates); and Participants' Training. For the Implementation Sphere, there are the categories Teaching Modality and Participants, as shown in Figure 4.

\begin{tabular}{|c|c|c|c|c|c|}
\hline \multirow[b]{2}{*}{ Author } & \multicolumn{3}{|c|}{ Elaboration Sphere } & \multicolumn{2}{|c|}{ Implementation Sphere } \\
\hline & $\begin{array}{l}\text { Elaboration } \\
\text { Space }\end{array}$ & Developers & $\begin{array}{l}\text { Training of } \\
\text { developers }\end{array}$ & $\begin{array}{l}\text { Teaching } \\
\text { Modality }\end{array}$ & Participants \\
\hline Amaral, G. & PIBID & $\mathrm{G}-\mathrm{BET}-\mathrm{UT}$ & Chemistry & $\begin{array}{l}\text { Technical } \\
\text { course }\end{array}$ & Students \\
\hline $\begin{array}{l}\text { Fernandes } \\
\text { F. G. }\end{array}$ & Internship & $\mathrm{G}-\mathrm{BET}-\mathrm{UT}$ & $\begin{array}{l}\text { Chemistry, } \\
\text { Physics, } \\
\text { Biology }\end{array}$ & $\begin{array}{l}\text { Technical } \\
\text { course }\end{array}$ & Students \\
\hline $\begin{array}{l}\text { Pinto, J. G. } \\
\text { R. }\end{array}$ & PIBID & $\mathrm{G}-\mathrm{BET}-\mathrm{UT}$ & $\begin{array}{l}\text { Teaching } \\
\text { Modality }\end{array}$ & $\begin{array}{l}\text { Technical } \\
\text { course }\end{array}$ & Students \\
\hline $\begin{array}{l}\text { Bomfim, R. } \\
\text { C. }\end{array}$ & GPeCFEC & $\mathrm{G}-\mathrm{BET}-\mathrm{UT}$ & Chemistry & $\begin{array}{l}\text { Elementary } \\
\text { school }\end{array}$ & Students \\
\hline $\begin{array}{l}\text { Pimenta, S. } \\
\text { S. }\end{array}$ & GPeCFEC & $\mathrm{G}-\mathrm{BET}-\mathrm{UT}$ & Chemistry & $\begin{array}{l}\text { Technical } \\
\text { course }\end{array}$ & Students \\
\hline $\begin{array}{l}\text { Reis, C. M. } \\
\text { R. }\end{array}$ & PIBID & $\mathrm{G}-\mathrm{BET}-\mathrm{UT}$ & Chemistry & $\begin{array}{l}\text { Youth and } \\
\text { Adults } \\
\text { Education }\end{array}$ & Students \\
\hline $\begin{array}{l}\text { Guimarães, } \\
\text { T. S. }\end{array}$ & $\begin{array}{l}\text { School - } \\
\text { GPeCFEC }\end{array}$ & $\mathrm{G}-\mathrm{UT}-\mathrm{PG}$ & $\begin{array}{l}\text { Chemistry, } \\
\text { Physics, } \\
\text { Biology }\end{array}$ & $\begin{array}{l}\text { Integrate } \\
\text { Complex of } \\
\text { Education }\end{array}$ & Students \\
\hline $\begin{array}{l}\text { Sampaio, } \\
\text { T. S. }\end{array}$ & $\begin{array}{l}\text { GPeCFEC - } \\
\text { School }\end{array}$ & $\mathrm{G}-\mathrm{BET}-\mathrm{UT}$ & $\begin{array}{l}\text { Chemistry, } \\
\text { Biology, } \\
\text { Agronomy }\end{array}$ & $\begin{array}{l}\text { Not } \\
\text { applicable }\end{array}$ & $\begin{array}{l}\text { Not } \\
\text { applicable }\end{array}$ \\
\hline Silva, U. K. & GPeCFEC & $\mathrm{G}-\mathrm{BET}-\mathrm{UT}$ & $\begin{array}{l}\text { Chemistry, } \\
\text { Biology }\end{array}$ & High School & Students \\
\hline $\begin{array}{l}\text { Silva, L. N. } \\
\text { C. }\end{array}$ & GPeCFEC & $\mathrm{G}-\mathrm{BET}-\mathrm{UT}$ & Chemistry & High School & Students \\
\hline $\begin{array}{l}\text { Resende, R. } \\
\text { C. S. }\end{array}$ & School & BET - UT - G & $\begin{array}{l}\text { Chemistry, } \\
\text { Physics, } \\
\text { Biology }\end{array}$ & $\begin{array}{l}\text { Elementary } \\
\text { school }\end{array}$ & Students \\
\hline
\end{tabular}

Figure 4. Spheres of the reconfiguration proposals developed in the context of the GP (to be continued) 


\begin{tabular}{|c|c|c|c|c|c|}
\hline \multirow[b]{2}{*}{ Author } & \multicolumn{3}{|c|}{ Elaboration Sphere } & \multicolumn{2}{|c|}{ Implementation Sphere } \\
\hline & $\begin{array}{l}\text { Elaboration } \\
\text { Space }\end{array}$ & Developers & $\begin{array}{l}\text { Training of } \\
\text { developers }\end{array}$ & $\begin{array}{l}\text { Teaching } \\
\text { Modality }\end{array}$ & Participants \\
\hline Jesus, D. & $\begin{array}{l}\text { Postgraduate } \\
\text { Program }\end{array}$ & $\begin{array}{l}\text { BET - UT } \\
-\mathrm{G}\end{array}$ & $\begin{array}{l}\text { Chemistry, } \\
\text { Physics }\end{array}$ & High School & Students \\
\hline $\begin{array}{l}\text { Almeida, C. } \\
\text { L. S }\end{array}$ & $\begin{array}{l}\text { School - } \\
\text { GPeCFEC }\end{array}$ & $\begin{array}{l}L-P G-P U \\
-P E\end{array}$ & $\begin{array}{l}\text { Chemistry, } \\
\text { Biology, } \\
\text { Pedagogy }\end{array}$ & $\begin{array}{l}\text { Rural } \\
\text { Education }\end{array}$ & $\begin{array}{l}\text { Basic Education } \\
\text { Teachers }\end{array}$ \\
\hline $\begin{array}{l}\text { Alves, W. } \\
\text { F. S. }\end{array}$ & Internship & $\begin{array}{l}\text { G - BET - } \\
\mathrm{UT}-\mathrm{PG}\end{array}$ & $\begin{array}{l}\text { Chemistry, } \\
\text { Physics, } \\
\text { Biology }\end{array}$ & $\begin{array}{l}\text { Not } \\
\text { applicable }\end{array}$ & Not applicable \\
\hline $\begin{array}{l}\text { Peixoto, C. } \\
\text { A. S. }\end{array}$ & GPeCFEC - & $\mathrm{BET}-\mathrm{PG}$ & $\begin{array}{l}\text { Chemistry, } \\
\text { Biology, } \\
\text { Pedagogy }\end{array}$ & $\begin{array}{l}\text { Not } \\
\text { applicable }\end{array}$ & Not applicable \\
\hline Sousa, P. S. & Internship & $\begin{array}{l}\text { G - BET - } \\
\mathrm{UT}-\mathrm{PG}\end{array}$ & $\begin{array}{l}\text { Chemistry, } \\
\text { Physics, } \\
\text { Biology }\end{array}$ & $\begin{array}{l}\text { Not } \\
\text { applicable }\end{array}$ & Not applicable \\
\hline $\begin{array}{l}\text { Bomfim, R. } \\
\text { C. }\end{array}$ & $\begin{array}{l}\text { School - } \\
\text { GPeCFEC }\end{array}$ & $\begin{array}{l}\mathrm{L}-\mathrm{PEB}-\mathrm{PU} \\
-\mathrm{PG}\end{array}$ & $\begin{array}{l}\text { Chemistry, } \\
\text { Physics, } \\
\text { Biology }\end{array}$ & $\begin{array}{l}\text { Integrating } \\
\text { Complex of } \\
\text { Education } \\
\end{array}$ & Students \\
\hline $\begin{array}{l}\text { Silva, F. N. } \\
\text { S. }\end{array}$ & GPeCFEC & $\begin{array}{l}\mathrm{G}-\mathrm{PG}-\mathrm{UT} \\
-\mathrm{D}\end{array}$ & $\begin{array}{l}\text { Chemistry, } \\
\text { Biology, } \\
\text { Pedagogy }\end{array}$ & $\begin{array}{l}\text { Integrated } \\
\text { Center }\end{array}$ & $\begin{array}{l}\text { Management, } \\
\text { coordination and } \\
\text { Basic Education } \\
\text { Teachers }\end{array}$ \\
\hline
\end{tabular}

Figure 4. Spheres of the reconfiguration proposals developed in the context of the GP (continuation)

Source: Research data, 2019.

The variables that constitute the Elaboration Sphere point to the existence of a Space for the Study of Action and a Collaborative Community. The Space for the Study of Action is the universe that propitiates the construction of the Integrating Scenario because: 1) it has access to school and academic institutions (Possible Spaces of Action) foreseen by its project; 2 ) it has physical spaces for meetings and meetings; 3 ) it facilitates the relationship and communication among individuals willing to reconfigure the school curriculum constituting a Collaborative Community.

The researches analyzed point to the need to build reconfiguration proposals in collaboration with different actors from different backgrounds, as several difficulties were encountered when the proposals were developed outside this format. Thus, we adopted that the Collaborative Community can be composed of any individuals who have a student, academic, professional or collaborative relationship with a school, being these: students, undergraduates, postgraduates, teachers of Basic Education, university 
teachers, education professionals, members of social movements, members of NGOs, members of neighborhood associations and others, as long as they are related and can help in the unfolding of the chosen theme. In this way, the development of the proposal can create connections between university, school, and society, as shown in Figure 5.

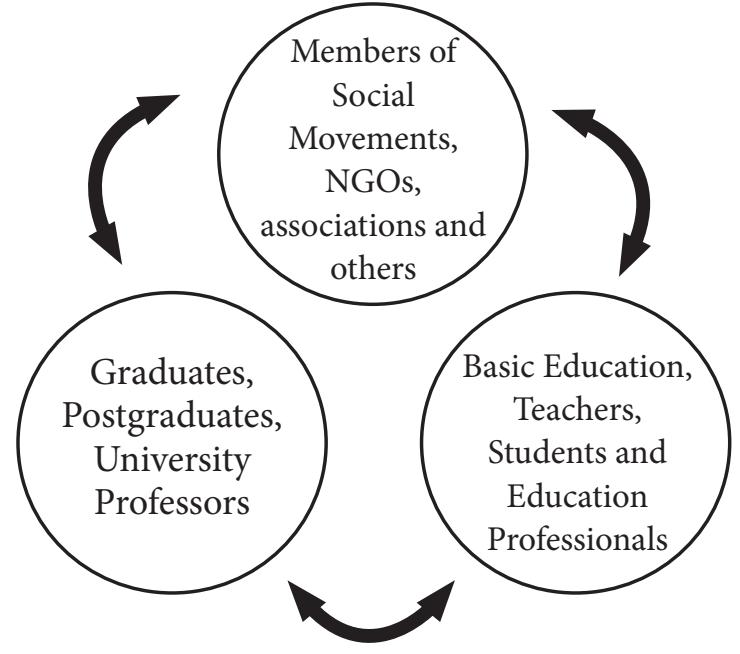

Figure 5. Collaborative community

Source: Research data, 2019.

A community is constituted by the common interest of individuals. Thus, the Collaborative Community is characterized by the integration of individuals ready to reconfigure the curriculum, to promote a quality education and teaching, concerned with social, historical, political and economic factors, in addition to scientific content.

It is possible that the proposal of curriculum reconfiguration reaches greater complexity of the subject to be developed, due to the fact that the members of this community have different experiences in social and academic areas. And that they are also willing to work in favor of the reconfiguration of the curriculum, because "the struggles in education and around it can have an effect on society as a whole" (Apple, 2017a, p. 37).

However, it should be emphasized that it will not always be possible for all the subjects of the elaboration community to participate, since each one fulfills different duties and agendas, which can make it difficult for everyone to meet. Furthermore, the lack of one of these representatives does not disfigure the Collaborative Community, in view of its definition pointed out above.

The main functions of this community are a) to promote possible spaces for action; b) to investigate the emergence of a theme of social and scientific relevance (with the characteristics of the theme) from the social context of the school and its surroundings; c) to build the proposal of curricular reconfiguration, being concerned with linking the contents and concepts to the chosen theme and engaging critically in the study of these themes; d) connect educational practices to local, regional, national, and global social issues (Apple, 2017a); e) be available to develop not only pedagogical interests, but also 
to act in support of social groups and movements (Apple, 2017a).

In view of these functions, it is important to know that educational issues are usually originated in structural problems and do not consider a critical perspective, since the duties and diverse problems faced in education occupy a large part of their tasks, time and attention of educators (Apple, 1989). So, if educators do not find themselves, at least in part, responsible for the critical tradition, and responsible for what is institutionally and culturally built, it will be difficult to rebuild this system (Apple, 2006).

Thus, given the role of the university and its commitment to developing teaching, research, and extension, it has also presented itself as a promoter of curricular reconfiguration, bearing in mind that in the $\mathrm{CCP}$ and thesis analyzed, the following spaces for the study of the action have been identified: The Institutional Program of Initiation to Teaching Scholarships (PIBID); the Supervised Internship; the research group. These spaces meet different objectives, but are similar in terms of the relationship maintained between university and school through their participants.

The PIBID, in which these researches were carried out, was the Chemistry subproject. In this space, the participants have different levels of training, being undergraduates, teachers of basic education and university professors, all with initial training in Chemistry. Therefore, the elaborated proposals focused on this discipline, even if other disciplines are involved.

The Supervised Internship in the Degree in Chemistry also provides for the mutual relationship between teachers of different levels of training. However, according to the researches analyzed, the elaboration communities were more diversified with the participation of subjects from different areas of formation, being this possible because in this space projects were developed considering the education through research as pointed out by Massena and Brito (2015), Alves (2018) and Sousa (2018) in their texts.

The space of GPeCFEC, in turn, is the meeting point for the elaboration of these researches. It is within the group that are produced proposals for curriculum reconfiguration, either in research projects, with the participation of Scientific Initiation Scholars (CI), university professors (the latter also responsible for managing the group), undergraduates in the development of CBT and master students in the development of thesis. The group, in its majority, consists of participants with a degree in Chemistry, but also has the participation of graduates in Physics, Biology and Pedagogy.

GPeCFEC has formed partnerships with schools in the region, which allows the presence of the group within the school, facilitating the participation of basic education teachers from different backgrounds in the Collaborative Community, both in the process of elaboration and in the implementation of curricular reconfiguration proposals. These schools operate in different modalities of education and have different curricular structures from regular schools (Resende, 2013; Bomfim, 2016), being this a characteristic of the Implementation Sphere, as shown in Figure 5.

The Implementation Sphere is the set of elements involved in the school or academic environment where the curriculum will be reconfigured. In this sphere, there 
must be a possible Space for action, that is, "spaces in which more progressive and antihegemonic actions can continue" or be initiated (Apple, 2017, p. 76) so that the proposal and research developed can achieve transformations and be credited. The analysis of the proposals developed in different teaching modalities points to a predisposition for a curricular reconfiguration that is developed from themes, thus configuring spaces for possible action.

In the Technical Education modality (Amaral, 2013; Pimenta, 2016), students must choose a career in the first year of high school and, during this period, study only career-oriented subjects. For example, in the Technical Course on Biofuels, the subjects offered are General Chemistry, Analytical, Inorganic and Organic, and at the end of the course, students must present a CCP related to the theme of biofuels.

In the modality Youth and Adult Education (EJA) (Reis, 2016; Sampaio, 2017), the curriculum is based on Formative Times, Thematic Axes and Generating Themes, and the disciplines are grouped by areas of knowledge.

In the Integrated Education Complex of Itabuna (Guimarães, 2017), integral school education is worked on and its hours are divided into four periods during the day. Thus, the first and third periods are dedicated to the subjects, while the second and fourth periods are reserved for the Knowledge Stations, spaces organized by means of themes in order to work interdisciplinary with multi-serialized classes. Multiserialization is also a reality in the schools of Rural Education (Almeida, 2017) and in the Florestan Fernandes Integrated Center (Silva, 2019) although these are configured in particular contexts.

According to what has been presented, the portion of culture displayed in the curricular reconfiguration proposals is defined and transformed by the spheres of elaboration and implementation, therefore, the context and the individuals that constitute these spheres act in the selection of teaching contents, those tacit and explicit (Sacristán, 1998).

The two spheres constitute important characteristics for the choice of themes that have social relevance and that are propitious for the teaching of Sciences. Thus, the members of the Collaborative Community must move from one sphere to another, dynamizing the study of theory and practice, since theory has no meaning without the real struggles faced in school (Apple, 2017).

\section{The Theme Selection Process in Integrating Scenarios}

In the approach by themes for a proposal, it is necessary to have a theoretical study of the emerging theme and the strategies and methods adopted in the planning, but, above all, it is necessary to know intimately the school space, the problematic situations of this environment and the reality of its surroundings.

Figure 6 below presents the chosen themes, the titles of the proposals, the authors' justifications for choosing the theme, the disciplines in which the proposals were concentrated, and the strategies and instruments used in the classes as pointed 
out by the researches that aimed at elaborating and implementing the proposal of reconfiguration and training courses. The researches that aimed at curriculum analysis and bibliographic survey are not listed in Figure 6, as they did not develop a proposal for curriculum reconfiguration.

\begin{tabular}{|c|c|c|c|c|}
\hline Author & Title (Theme) & Justification & Discipline & $\begin{array}{l}\text { Strategies and } \\
\text { Instruments }\end{array}$ \\
\hline Amaral, G. & $\begin{array}{l}\text { Straighteners: } \\
\text { A way to teach } \\
\text { concentration }\end{array}$ & $\begin{array}{l}\text {-Scientific contents } \\
\text {-Future professional } \\
\text { performance } \\
\text {-Considers the } \\
\text { curriculum }\end{array}$ & Chemistry & $\begin{array}{l}\text { Conversation, } \\
\text { questionnaire, } \\
\text { research, lecture, } \\
\text { Chemical Jury, } \\
\text { experimental activity, } \\
\text { summary, test. }\end{array}$ \\
\hline $\begin{array}{l}\text { Fernandes } \\
\text { F. G. }\end{array}$ & $\begin{array}{l}\text { Cleaning } \\
\text { products }\end{array}$ & $\begin{array}{l}\text {-Scientific contents } \\
\text {-Future professional } \\
\text { performance } \\
\text {-Considers the } \\
\text { curriculum }\end{array}$ & Chemistry & $\begin{array}{l}\text { Questionnaire, } \\
\text { lecture, text, } \\
\text { lecture, videos, } \\
\text { oral evaluation, } \\
\text { exercises. }\end{array}$ \\
\hline $\begin{array}{l}\text { Pinto, J. G. } \\
\text { R. }\end{array}$ & $\begin{array}{l}\text { Self-medication, a } \\
\text { necessary harm? }\end{array}$ & $\begin{array}{l}\text {-Current Theme } \\
\text {-Social elevation } \\
\text {-Future professional } \\
\text { performance } \\
\text {-Considers the } \\
\text { curriculum }\end{array}$ & Chemistry & $\begin{array}{l}\text { Text, video, Jigsaw, } \\
\text { questionnaire, TV } \\
\text { pen drive, lecture, } \\
\text { debate, experiment, } \\
\text { textual production, } \\
\text { exercises, proof. }\end{array}$ \\
\hline $\begin{array}{l}\text { Bomfim, R. } \\
\text { C. }\end{array}$ & Self-medication & $\begin{array}{l}\text {-Interdisciplinary } \\
\text { scientific content } \\
\text {-Socio-cultural issues }\end{array}$ & $\begin{array}{l}\text { Chemistry, } \\
\text { Biology }\end{array}$ & $\begin{array}{l}\text { Questionnaire, } \\
\text { lecture, lecture, } \\
\text { videos, discussion, } \\
\text { reading of the } \\
\text { booklet, construction } \\
\text { of posters, resolution } \\
\text { of exercises. }\end{array}$ \\
\hline $\begin{array}{l}\text { Pimenta, } \\
\text { S. S. }\end{array}$ & $\begin{array}{l}\text { The science that } \\
\text { curls need: No poo } \\
\text { and Low poo }\end{array}$ & $\begin{array}{l}\text {-Current Theme } \\
\text {-Social Context } \\
\text {-Interdisciplinary } \\
\text { scientific content }\end{array}$ & $\begin{array}{l}\text { Chemistry, } \\
\text { Biology, } \\
\text { Physics }\end{array}$ & $\begin{array}{l}\text { Round of } \\
\text { conversation, lecture, } \\
\text { exhibition of images, } \\
\text { analysis of labels, } \\
\text { experiment, report, } \\
\text { textual production, } \\
\text { exercise, proof. }\end{array}$ \\
\hline
\end{tabular}

Figure 6. Structuring of the curricular reconfiguration proposals elaborated (to be continued)

Source. Research data, 2019. 


\begin{tabular}{|c|c|c|c|c|}
\hline Author & Title (Theme) & Justification & Discipline & $\begin{array}{l}\text { Strategies and } \\
\text { Instruments }\end{array}$ \\
\hline $\begin{array}{l}\text { Reis, C. M. } \\
\text { R. }\end{array}$ & $\begin{array}{l}\text { Me, chemistry } \\
\text { and garbage: } \\
\text { Everything to do } \\
\text { with it }\end{array}$ & $\begin{array}{l}\text {-Social elevation } \\
\text {-Local context }\end{array}$ & $\begin{array}{l}\text { Chemistry, } \\
\text { Arts, Physics, } \\
\text { Biology. } \\
\text { Mathematics. }\end{array}$ & $\begin{array}{l}\text { Questionnaire, } \\
\text { films, poster, } \\
\text { lecture, videos, } \\
\text { experiment, test } \\
\text { exercises, elaboration } \\
\text { of pamphlets, } \\
\text { confection of } \\
\text { materials, oral } \\
\text { presentation, group } \\
\text { work, exhibition. }\end{array}$ \\
\hline $\begin{array}{l}\text { Guimarães, } \\
\text { T. S. }\end{array}$ & $\begin{array}{l}\text { Chocolate } \\
\text { Chemistry and } \\
\text { Jorge Amado's } \\
\text { cocoa }\end{array}$ & $\begin{array}{l}\text {-Regional context } \\
\text {-Interdisciplinary } \\
\text { scientific and } \\
\text { humanities content } \\
\text {-Social, cultural, and } \\
\text { economic issues }\end{array}$ & $\begin{array}{l}\text { Chemistry, } \\
\text { Literature, } \\
\text { Biology, } \\
\text { History, } \\
\text { Geography. }\end{array}$ & $\begin{array}{l}\text { Questionnaire, } \\
\text { logbook, literature } \\
\text { book reading, } \\
\text { dynamics, discussion, } \\
\text { didactic game, } \\
\text { report. }\end{array}$ \\
\hline $\begin{array}{l}\text { Sampaio, } \\
\text { T. S. }\end{array}$ & Ecology & $\begin{array}{l}\text {-Interdisciplinary } \\
\text { scientific content } \\
\text {-Considers the } \\
\text { curriculum } \\
\text {-Social elevation }\end{array}$ & $\begin{array}{l}\text { Chemistry, } \\
\text { Biology, } \\
\text { Physics and } \\
\text { Mathematics }\end{array}$ & $\begin{array}{l}\text { Research, oral } \\
\text { presentation, } \\
\text { photography, posters, } \\
\text { textual production, } \\
\text { dramatization, } \\
\text { debate, newspaper. }\end{array}$ \\
\hline Silva, U. K. & $\begin{array}{l}\text { Almada River } \\
\text { Water }\end{array}$ & $\begin{array}{l}\text {-Regional context } \\
\text {-Interdisciplinary } \\
\text { scientific concepts } \\
\text {-Humanities } \\
\text { content }\end{array}$ & $\begin{array}{l}\text { Chemistry, } \\
\text { Biology, } \\
\text { Mathematics, } \\
\text { History, } \\
\text { Geography, } \\
\text { Portuguese } \\
\text { Sociology }\end{array}$ & $\begin{array}{l}\text { Dialogue, drawing, } \\
\text { model, script, } \\
\text { label analysis, } \\
\text { image exhibition, } \\
\text { experiment, jigsaw, } \\
\text { text, discussion. }\end{array}$ \\
\hline $\begin{array}{l}\text { Silva, L. N. } \\
\text { C }\end{array}$ & $\begin{array}{l}\text { The water quality } \\
\text { of the Cachoeira } \\
\text { River }\end{array}$ & $\begin{array}{l}\text {-Local and regional } \\
\text { context } \\
\text {-Scientific contents }\end{array}$ & Chemistry & $\begin{array}{l}\text { Questionnaire, video, } \\
\text { discussion, dialogue } \\
\text { class, narrative, group } \\
\text { activity, field trip, } \\
\text { experimentation. }\end{array}$ \\
\hline $\begin{array}{l}\text { Resende, R. } \\
\text { C. S. }\end{array}$ & $\begin{array}{l}\text { Food: Production } \\
\text { and consumption }\end{array}$ & $\begin{array}{l}\text {-Students' daily life } \\
\text {-Interdisciplinary } \\
\text { scientific content }\end{array}$ & $\begin{array}{l}\text { Chemistry, } \\
\text { Biology, } \\
\text { Physics }\end{array}$ & $\begin{array}{l}\text { Discussions, } \\
\text { readings, video and } \\
\text { label analysis, food } \\
\text { production, film, } \\
\text { textual production, } \\
\text { evaluation, snack. }\end{array}$ \\
\hline
\end{tabular}

Figure 6. Structuring of the curricular reconfiguration proposals elaborated (to be continued) 


\begin{tabular}{|c|c|c|c|c|}
\hline Author & Title (Theme) & Justification & Discipline & $\begin{array}{l}\text { Strategies and } \\
\text { Instruments }\end{array}$ \\
\hline Jesus, D. & Our daily coffee & $\begin{array}{l}\text {-Students' daily life } \\
\text {-Historical and } \\
\text { interdisciplinary } \\
\text { scientific content } \\
\text {-Global beauty }\end{array}$ & $\begin{array}{l}\text { Chemistry, } \\
\text { Physics and } \\
\text { Biology, } \\
\text { History }\end{array}$ & $\begin{array}{l}\text { History, discussion, } \\
\text { video, group work, } \\
\text { experiment, practical } \\
\text { activity, jigsaw, } \\
\text { lecture, graph } \\
\text { making, tasting, } \\
\text { script, report, image } \\
\text { exhibition }\end{array}$ \\
\hline $\begin{array}{l}\text { Almeida, C. } \\
\text { L. S }\end{array}$ & $\begin{array}{l}\text { Generation and } \\
\text { management of } \\
\text { solid waste from } \\
\text { human activities }\end{array}$ & $\begin{array}{l}\text {-Students' daily life } \\
\text {-Scientific contents }\end{array}$ & $\begin{array}{l}\text { Chemistry, } \\
\text { Physics and } \\
\text { Biology, } \\
\text { Arts. }\end{array}$ & $\begin{array}{l}\text { Video, discussion, } \\
\text { practical activities } \\
\text { (handcrafted } \\
\text { recycling of paper } \\
\text { and construction of } \\
\text { a household compost } \\
\text { shop), workshop. }\end{array}$ \\
\hline $\begin{array}{l}\text { Peixoto, C. } \\
\text { A. S. }\end{array}$ & Sustainability & $\begin{array}{l}\text {-Interdisciplinary } \\
\text { scientific content }\end{array}$ & $\begin{array}{l}\text { Chemistry, } \\
\text { Physics, Arts, } \\
\text { Biology, } \\
\text { Geography, } \\
\text { Portuguese, } \\
\text { Spanish }\end{array}$ & $\begin{array}{l}\text { Dynamics, dialogue, } \\
\text { texts. }\end{array}$ \\
\hline \multirow{2}{*}{$\begin{array}{l}\text { Bomfim, R. } \\
\text { C. }\end{array}$} & $\begin{array}{l}\text { 1.Move with the } \\
\text { Sciences }\end{array}$ & $\begin{array}{l}\text {-Local Relevance } \\
\text {-Interdisciplinary } \\
\text { scientific content }\end{array}$ & $\begin{array}{l}\text { Chemistry, } \\
\text { Physics and } \\
\text { Biology }\end{array}$ & $\begin{array}{l}\text { 1. experiment, } \\
\text { discussion, text, } \\
\text { table construction, } \\
\text { food pyramid } \\
\text { construction, } \\
\text { reports. }\end{array}$ \\
\hline & $\begin{array}{l}\text { 2. give a like in life: } \\
\text { licit drugs }\end{array}$ & $\begin{array}{l}\text {-Interdisciplinary } \\
\text { scientific and } \\
\text { humanities content } \\
\text {-Social, political, and } \\
\text { economic issues }\end{array}$ & $\begin{array}{l}\text { Chemistry, } \\
\text { Biology, } \\
\text { Physics }\end{array}$ & $\begin{array}{l}\text { 2. Serial excerpts, } \\
\text { discussions, reports, } \\
\text { group activity, } \\
\text { jury, text, video, } \\
\text { documentary, stand } \\
\text { in science fair. }\end{array}$ \\
\hline $\begin{array}{l}\text { Silva, F. S. } \\
\text { S. }\end{array}$ & $\begin{array}{l}\text { Study Situation in } \\
\text { the Formation of } \\
\text { MST Educators: } \\
\text { Rethinking the } \\
\text { School Curriculum } \\
\text { from the Healthy } \\
\text { Eating Theme }\end{array}$ & $\begin{array}{l}\text {-Local relevance } \\
\text {-Teachers' Lives } \\
\text {-Interdisciplinary } \\
\text { scientific content } \\
\text {-Social Context } \\
\text {-Cultural issues }\end{array}$ & $\begin{array}{l}\text { Chemistry, } \\
\text { Biology }\end{array}$ & $\begin{array}{l}\text { Reading, discussion } \\
\text { and socialization in } \\
\text { group, texts, video, } \\
\text { experiments, textual } \\
\text { productions. }\end{array}$ \\
\hline
\end{tabular}

Figure 6. Structuring of the curricular reconfiguration proposals elaborated (continuation)

Source. Research data, 2019. 
According to Figure 6, the most frequent themes were: environment, food, and cosmetic products. It is perceived that great part of the chosen themes considers at least three aspects, such as the context of the participants, themes that provoke desired contents, and the school curriculum.

When new approaches are suggested to teachers of Basic Education, one of the concerns that arises is about the curriculum segment, being common to request that the contents be maintained. Concerns also arise regarding how long the proposal implementation period is and when it can be implemented since the school complies with timetables, delivery deadlines, exam periods and other activities. Regarding these aspects, Sacristán (1998) recalls well that

The teacher does not work in a vacuum, but within organizations that regulate practices: the conditions of schooling, the regulation of the curriculum carried out outside the classroom and the flexibility to develop the work of teachers. The professional autonomy possible for the teachers of a school resides in the frontier terrain that generates the dialectics between the external pressures and the practice that can be elaborated in the organizational framework of each school. It is a field that can be used or not depending on the teacher's education and the degree of association between individuals (Sacristán, 1998, p. 207).

Therefore, during the elaboration of proposals for curricular reconfiguration, it is necessary to consider the reality of the school and the teacher collaborator of Basic Education regarding the conditions of their professional exercise (Sacristán, 1998).

In this sense, thinking about the dynamics of schools, the proposals implemented in Basic Education lasted from one to four months, lasting on average one school unit, and are generally divided into four (4) moments. Also, in some proposals, the theme was chosen from the contents foreseen in the annual plan of the teacher so that the curriculum of the subject could be concluded. Even in these cases, the reconfiguration of the curriculum is considered, as the sequence of contents was changed to be discussed interdisciplinary. Furthermore, these contents are introduced through a wide variety of strategies and instruments that help to discuss social and political dimensions related to the subject, such as videos, reading of texts and the discussion itself.

On some occasions, there was a certain difficulty for teachers of Basic Education to participate effectively and take ownership of the development of the curricular reconfiguration, but it is important to emphasize that in cases where the school was involved in broader activities and projects, and the school program was respected in the elaboration of the proposal, teachers of other disciplines such as Arts, Biology, Geography, and History participated more easily in its implementation (Reis, 2016; Sampaio, 2017).

The analyzed proposals also point out a concern to discuss the context of students, both at the level of daily life - themes present in the daily lives of students that usually raise the interdisciplinary disciplines of Science to discuss curiosities and focus on dialectics teaching and learning, as in the proposal "Our daily coffee" (Jesus, 
2015); or at the level of social issues - themes that require dialogue between the areas of Science and Humanities, awaken scientific knowledge by raising the critical thinking of students on social issues as in "Food Sovereignty" (Silva, 2019) and "Jorge Amado's cocoa" (Guimarães, 2017).

In the Integrating Scenario, it is desired that the themes for the reconfiguration of the curriculum be of social relevance, that they raise actions to transform reality so that the construction of the planned proposal is developed from a social perspective. The analyzed proposals are considered to point to a movement that goes from promoting techno-science to activism (Simonneaux, 2014).

Thus, the proposals that restrict themselves to valuing the daily life and future professional performance of students and that consider the curricular sequence of scientific contents as a starting point for the development of the curricular reconfiguration proposal tend to present low levels of activism. An example of this is the proposals presented in the works of Amaral (2013), Fernandes (2014), and Pinto (2015), which have as a starting point the content, demonstrating a techno-scientific concern, with the learning of concepts and scientific knowledge (Simonneaux, 2014).

In another direction, the proposals that present levels of activism from intermediary to high, are committed developing themes of local relevance according to the social context in which the school is inserted, with interdisciplinary scientific contents and cultural issues. Some proposals that have been developed have these characteristics, as well as the works of Bomfim (2019) and Silva (2019), although in these works no activist actions outside the school scope are verified.

Thinking about the development of curricular proposals that promote social actions, we corroborate Apple's ideas $(1989 ; 2011 ; 2017 a ; 2017 b)$ when he suggests that the educator should be an intellectual activist. Therefore, understanding the schools and acting in them is not enough, it is necessary to use it to generate significant actions. For culture is not in itself neutral, but it is an element that helps to keep inequality out of school (Apple, 2006).

On this issue, Apple (2011; 2017 a; 2017 b) emphasizes that the researcher who intends to be a "critical scholar/activist" must extrapolate the theory to realize transformations in the real world. According to the author, "The theory "really rules," with few exceptions, in the reality of institutions, communities and their struggles. For these people, reality has become a "text" a subject for deconstruction, but with little concrete action in solidarity with the oppressed". (Apple, 2017 a, p. 70). According to Moreira (1989, p. 25), Apple presents "the need to always think of the curriculum in relation to the broader social context," so the use of themes involving race, gender, and class can confer high levels of activism,

[...] it is important to realize that education is part of society. It is not something that stays outside. In fact, it is a primordial set of institutions and a primordial set of social and personal relationships. It is simply central to a society [...] where people and power interact (Apple, 2017, p. 39). 
In this thought, it is oriented that the choice of the theme occurs in the dynamics between the Elaboration Sphere and the Implementation Sphere. It is believed that the closer the participants of the Collaborative Community get to the space of action possible, the emergence of a theme of high social relevance for the subjects of the sphere of implementation will be more easily evidenced being possible to plan and carry out activist actions.

In order for educators to be capable of this transformation, it is necessary to deeply understand the relationships between education and the ideological, political and economic spheres, and how these relationships are present in the school (Apple, 1989). Educators as subjects involved in the school environment must have the task of studying daily activities by examining them for political and economic factors. This, however, is not enough to promote changes in daily practices.

\section{Outlining issues of social relevance in the school context}

Taking into account the ideas presented above, three steps are suggested to enable the emergence process of the theme:

1. Knowing the school context - This stage consists in knowing the school's or subject's curriculum, knowing the school's projects, identifying teachers, education professionals and students who are willing to participate in the Collaborative Community and, for that, some intervening activities can be carried out at the school (Apple, 1999).

2. To particularize the school reality - The identification of the theme requires "particularizing the reality" and the selection of culture that is preserved and distributed at school (Sacristán, 1998; Apple, 2006). This stage consists in investigating the theme through conversations with students, teachers and school staff and, if possible, with residents around the school. Information can be collected through questionnaires, interviews and conversation wheels.

3. Extrapolating local reality - The particularity of school reality does not say everything about the problems it faces, so it is necessary to identify which aspects of the broader global problems manifest themselves there. For this, it is possible to follow the school activity to identify attitudes that point to the hidden curriculum and ideological and hegemonic discourses (Silva, 1995; Apple, 2006). Thus, Apple (2006) suggests three issues that help identify these discourses and situate the reality of the school:

(1) how daily school norms contribute to students learning these ideologies; (2) how specific forms of curricular knowledge both in the past and today reflect these configurations, and (3) how these ideologies are reflected in the main perspectives that educators themselves employ to order, guide and give meaning to their own activity ( $\mathrm{p}$. 48).

Unveiling these elements can help in the development of a fairer curriculum. This can be accomplished with journal entries on school observations. It is possible that from this process different themes emerge, therefore, three desirable characteristics of this choice are pointed out below: 
- Present social relevance;

- Present scientific relevance;

- Awakening the discussion of issues of local, national and global dimension.

After the choice of theme, the document of the proposed reconfiguration can be developed by the Collaborative Community, considering steps that enable the teaching and learning of students and that raise actions to solve the problems related to the theme discussed. To do so, it is suggested to think about the set of four moments of learning, (Gehlen, Maldaner, Delizoicov, 2012) as follows:

1. Problematization - The Problematization is the moment in which the problems that emerge in the identification stages of the theme will be discussed with the students so that they expose their understanding of those found in their reality. For this, the teacher should direct the discussion so that it begins by addressing the dimension of the problem at the local level, starting with the regional, national and worldwide.

2. Study of the problem - This moment consists in the study of the problem with the necessary concepts and contents, either specific or related to the areas of humanities or nature sciences, so that there is initial knowledge of the academic content.

3. Function of knowledge - At this moment, the student must be able to explain the origin and consequence of the problem in its reality, which means consistency in advancing the understanding of the academic content for the resolution or positioning of the student regarding the problem.

These three moments contemplate a pedagogical objective in order for the student to develop the cognitive system, but do not foresee actions for the practical solution of the problem, so a fourth moment is suggested.

4. Activist action - This moment consists of teachers and students taking activist measures. To exemplify, when thinking about a theme such as "garbage", it is possible to carry out actions such as petitioning neighborhood residents or sending letters requesting garbage collection, creating plaques to avoid the disposal of garbage in inadequate places, carrying out task force for the collection. In this way, it is possible to teach science committed to society, not only witnessing negativity, but also acting for positive change (Apple, 2017).

Finally, it is understood that developing and implementing curriculum reconfiguration proposals in Integrating Scenarios is related to connecting individuals and schools to communities. In agreement with the words of Gandin and Apple:

We need to engage in the hard work of documenting current efforts to connect our educational work with local communities, especially those members of these less powerful communities, who are more truly democratic than the ideas of "thin" democracy envisioned by the right. If we do not do this, neoliberal definitions of democracy - based on possessive individualism and in which citizenship reduced to simple consumer practices - will prevail (Gandin, Apple, 2017 p. 165).

In this thinking, curricular reconfiguration proposals can be instruments for achieving change by empowering subordinate groups and allowing the voice of those 
who are part of these groups to be heard. Extrapolating the conceptual, content and technical focus of teaching when managed from a critical and activist perspective.

\section{Towards the conclusion}

Faced with the objective of presenting the emergency process and the rationale for the proposal of curricular reconfiguration Integrating Scenario, the documental analysis carried out in this article from the bibliographical survey of CCP and thesis produced within the scope of UESC for 10 years, allowed us to know the quantitative dimension of academic production within this group. In addition, it was possible to know how, which and why different conceptions of curricular reconfiguration are emerging in this context. It was then possible to perceive a process of non-conscious action-research, in which anomalies, problems, limitations and also possibilities were systematized and studied, giving rise to the Integrating Scenario.

According to what is presented in this article, we consider that the Integrating Scenario is a new proposal of curricular reconfiguration that promotes the teaching of Sciences through themes of social relevance developed in collaboration with agents who are willing to build and implement such proposal in order to reconfigure the curriculum.

Through the Elaboration and Implementation Sphere, this proposal has promoted the integration between school, academic and social spaces. It is important to emphasize that, due to the dynamic characteristic of the Spheres, once elaborated they should not be reproduced and applied a second time in the same school, class or in others. In case the theme is still relevant for that group, it is necessary that a new evaluation of the theme be carried out, so that the advances, peculiarities and differences of the problems that express this theme can be identified.

The structure of the Integrating Scenario emerged in the process of building this research and in a series of meetings of GPeCFEC. However, although there has been an advance in the structuring of this proposal, it is not finished, because the period of development of the research presented here is limited and would not support the study of factors such as interdisciplinary (intrinsic to the discussion of the subject), the development of the teacher in initial and continued formation in the Collaborative Community, the study of the cognitive development of the student made possible by teaching from the Integrating Scenario, among other questions that still have to be answered over the years by the research group.

The proposal to reconfigure the curriculum Integrating Scenario presented in this article is in itself a contribution to the scientific community because its development can promote a science teaching more committed to issues of social justice, integrating scientific knowledge to topics of social relevance. In addition, it is worth mentioning that GPeCFEC's performance through curricular reconfiguration proposals in this region has enabled graduate students to have a differentiated education, which opens possibilities for a more humanized future performance. Still from this perspective, Basic Education teachers have also been encouraged to participate in continuing education 
actions, not only informally as participants in the research group, but also through entry into Graduate Programs.

With this, it is understood that the Integrating Scenario proposal can be a promoter of science teacher training that is in line with the intrinsic and extrinsic needs of our society, having the potential to promote improvements in the quality of teaching and resignifying the social and cultural meaning of the school. In this sense, it is important to consider that the schools in which GPeCFEC has been acting, have been promoting the implementation of the reconfiguration proposal for at least ten years, which shows that the established partnership has had an effect, although this requires dedication and effort from all members. Moreover, many of the participants in this research group, who due to the continuous flow of permanence, are engaged in other contexts, other school realities in different cities of the region, end up being multipliers of this type of action by acting by valuing the school context and promoting positive changes in these spaces. Finally, we highlight that the research and actions promoted in this context have had a regional impact beyond the scientific commitment to schools, and are open to new horizons of implementation.

\section{Acknowledgements}

We would like to thank the funding agencies Bahia Research Support Foundation (FAPESB) and the Brazilian Federal Agency for Support and Evaluation of Graduate Education (CAPES) and the National Council for Scientific and Technological Development (CNPq); to Group of Study on Thematic Approach in Science Teaching (GEATEC/UESC) for discussing this text. Finally thank to the members of the Group for Research in Curriculum and Teacher Training in Science Teaching (GPeCFEC) from UESC.

\section{References}

Apple, M. W. (1989). Education and power. Routledge \& Kegan Paul.

Apple, M. W. (2000). Política cultural e educação [Cultural politics and education]. Cortez.

Apple, M. W. (2006). Ideologia e currículo [Ideology and curriculum]. 3. ed. Artmed.

Apple, M. W. (2011). Global Crises, Social Justice, and Teacher Education. Journal of Teacher Education. 62(2), 222-234. https://dx.doi.org/10.1177/0022487110385428

Apple, M. W. (2017 b). A luta pela democracia na educação crítica. [The struggle for democracy in critical education]. Revista e-Curriculum, 15(4), 894-926. https://dx.doi. org/10.23925/1809-3876.2017v15i4p894-926

Apple, M. W. (2017a) A educação pode mudar a sociedade? [Can Education Change Society?]. Vozes. 
Borba, F. S. (2004). Cenário. Borba, F. S. (org.). Dicionário UNESP do Português Contemporâneo. Ed. UNESP, São Paulo. 1470 p.

Campos, M. S. N., \& Reis, G. R. F. S. (2019). Os materiais narrativos e a reconfiguração dos currículos: Desafios e possibilidades [Narrative materials and the curriculum reconfiguration: Challenges and possibilities]. Currículo sem Fronteiras, 19(1), 396-417.

Delizoicov, D., Angotti, J. A., \& Pernambuco, M. M. (2011). Ensino de ciências: Fundamentos e métodos [Science teaching: Fundamentals and methods]. $4^{\mathrm{a}}$ ed. Cortez.

Gehlen, S. T. , Maldaner, O. A., \& Delizoicov, D. (2012). Momentos Pedagógicos e as etapas da Situação de Estudo: Complementaridades e Contribuições para a Educação em Ciências [Pedagogical moments and the stages of Study Situation: Complementarities and contributions to the Science Education]. Ciências e Educação, 18(1), 1-22. https:// doi.org/10.1590/S1516-73132012000100001

Guba, E. G. \& Lincoln, Y. S. (1981). Effective Evaluation. Ca. Jossey-Bass.

Kemmis, S. (2009). Action research as a practice-based practice. Educational Action Research, 17(3), 463-474. https://doi.org/10.1080/09650790903093284

Kemmis. S. \& Mctaggart. R. (Orgs.) (1988). The action Research planner. 3 ed. Geelong, Deakin University Press.

Kuhn, T. (1996). A estrutura das revoluções científicas [The Structure of Scientific Revolutions]. 4 ed. Perspectiva.

Ludke, M., \& André, M. E. D. A. (1986). Pesquisa em educação: Abordagens qualitativas [Education research: Qualitative approaches]. EPU.

Maia, R. (1995). Configuração. In R. Maia. Magno Dicionário Brasileiro da Língua Portuguesa. Edipar.

Maldaner, O. A. (2007). Situações de estudo no ensino médio: Nova compreensão de educação básica. In R. Nardi (Org.), A pesquisa em ensino de ciências no Brasil: Alguns recortes [Science education research in Brazil: Some excerpts]. (pp. 239-254). Escrituras.

Maldaner, O. A., \& Zanon, L. B. (2006). Situação de Estudo: Uma organização do ensino que extrapola a formação disciplinar em Ciências. In R. Moraes, R. Mancuso (Orgs.), Educação em Ciências: Produção de currículos e formação de professores [Science Education: Curriculum production and teacher training]. (pp. 43-175). Ed. UNIJUÍ.

Massena. E. P., \& Brito, L. D. (2015). Caminhos e descaminhos da Situação de Estudo (Situação de Estudo): A experiência vivenciada por um grupo de formadores de professores. In Masena, E. P. (Org). (2015). Situação de Estudo: Processo de significação pela pesquisa em grupos interinstitucionais. [Study Situation: Process of meaning through research in interinstitutional groups]. Ed. Unijuí. 
Mesquita, S. S. de A. (2019). A centralidade do papel dos professores do ensino médio na reconfiguração do currículo e da profissão [The centrality of the role of high school teachers in reconfiguring the curriculum and the profession]. Revista e-Curriculum, 17(1), 230-255. http://dx.doi.org/10.23925/1809-3876.2019v17i1p230-255

Moraes, R., \& Galiazzi, M. do C. (2013). Análise Textual Discursiva. [Analisis Textual Discursive]. 2 ed. Ed. UNIJUÍ.

Moreira, A. F. B. (1989). A contribuição de Michael Apple para o desenvolvimento. [Michael Apple's contribution to the development of a critical curriculum theory in Brazil]. Fórum educacional, 13(4),17-30.

Pansera-de-Araújo, M. C., Auth, M. A. E., \& Maldaner, O. A. (2007). Situações de Estudo como forma de inovação curricular em Ciências Naturais. In M. C. Galiazzi, M. A Auth, R. Moraes, \& R. Mancuso (Orgs.), Construção curricular em rede em educação na Educação em Ciências: Uma aposta de pesquisa na sala de aula [Curriculum construction in networked education in Science Education: A bet on research in the classroom]. (pp. 161-176). Ed. UNIJUÍ.

Pedretti, E., \& Nazir. J. (2011). Currents in STS Education: Mapping a Complex Field, 40 Years On. Science Education.

Ratcliffe M., \& Grace, M. (2003). Science education for citizenship: Teaching socioscientific issues. Maidenhead: Open University Press.

Sacristán, J. G. (1998). O currículo: Os conteúdos do ensino ou uma análise prática?. In J. G. Sacristán, \& A. I. Pérez-Gomez (Orgs.), Compreender e transformar o ensino [Understand and transform teaching]. (pp. 119-148) 4. ed. Tradução de: Ernani F. da Fonseca Rosa. Artmed.

Silva, T. T. (1995). Currículo e identidade social: Territórios contestados. In T. T. Silva (Org.), Alienígenas na sala de aula: Uma introdução aos estudos culturais em educação [Aliens in the classroom: an introduction to cultural studies in education]. (pp. 190207). 9 ed. Vozes.

Simonneaux, L. (2014). Questions Socialement Vives and Socio-scientific Issues: New Trends of Research to Meet the Training Needs of Postmodern Society. In C. Bruguière, A. Tiberghien, \& P. Clément (Éd.), Topics and Trends in Current Science Education: $9^{\text {th }}$ ESERA Conference Selected Contributions (pp. 37-54) (Contributions from Science Education Research Book 1). Dordrecht, The Netherlands: Spinger Verlag.

Tripp, D. (2005). Pesquisa-ação: Uma introdução metodológica [Action research: a methodological introduction]. Educ. Pesqui., 31(3), 443-466.

Vieira, L. B. G., Fernandes, G. W. R., Massena, E. P., \& Maldaner, O. A. (2018). Situação de Estudo: $\mathrm{O}$ que vem sendo publicado em eventos e periódicos da área de ensino de ciências? [The study situation: What has been published in events and journals on the science teaching field?] Revista Ensaio. Belo Horizonte, 20, e2914. https://doi. org/10.1590/1983-21172018200101 
Winter, R. (2005). Some Principles and Procedures for the Conduct of Action Research. In O. Zubert-Skerrtitt, (Org.). New directions in action research (pp. 9-22). Taylor \& Francis e-Library.

Ximenes, S. (2000). Integrar. Minidicionário da Língua Portuguesa [Mini Dictionary of Portuguese Language]. ed. 2. Ed. Ediouro.

Zubert-Skerrtitt, O. (2005). Emancipatory Action Research For Organisational Change and Management Development. In O. Zubert-Skerrtitt (Org.) New directions in action research (pp. 68-87). Taylor \& Francis e-Library.

\section{CCP References and Thesis used as data corpus}

Almeida, C. L. S. (2017). Situação de Estudo na formação de professores em escolas do campo de Coaraci-BA. [Study Situation in teacher training in rural schools in CoaraciBA] (Dissertação). Universidade Estadual de Santa Cruz-UESC, Ilhéus, Brasil.

Alves. W. F. S. (2018). Saberes Docentes na Formação Inicial de Professores de Ciências: (Re)pensando práticas educativas por meio da Situação de Estudo [Teaching Knowledge in the Initial Formation of Science Teachers: (re)thinking educational practices through the Ilhéus Study Situation]. (Dissertação). Universidade Estadual de Santa Cruz-UESC, Ilhéus, Brasil.

Amaral, G. (2013). Situação de Estudo: Uma nova abordagem curricular no curso técnico em Biotecnologia [Study Situation: A new curricular Approach in the technical course in Biotechnology]. (Monografia). Universidade Estadual de Santa Cruz-UESC, Ilhéus, Brasil.

Bomfim, R. C. (2016) Automedicação como tema de Situação de Estudo para o Ensino de Química [Self-medication as a Study Situation for the Teaching of Chemistry]. (Monografia). Universidade Estadual de Santa Cruz-UESC, Ilhéus, Brasil.

Bomfim, R. C. (2019). (Dissertação). O trabalho colaborativo na interface universidadeescola: (re)pensando o currículo por meio da Situação de Estudo [Collaborative work on the university-school interface: (re)thinking the curriculum through the Study Situation]. Universidade Estadual de Santa Cruz-UESC, Ilhéus, Brasil.

Fernandes. G. F. (2014). Contribuições da situação de estudo à formação inicial de professores de química da Universidade Estadual de Santa Cruz [Contributions from the Study Situation to the Initial Teacher Education in Chemistry at Santa Cruz State University]. (Monografia). Universidade Estadual de Santa Cruz-UESC, Ilhéus, Brasil.

Guimarães, T. S. (2017). O uso da literatura de Jorge Amado no Ensino de ciências: Uma possibilidade a partir de uma Situação de Estudo [The use of Jorge Amado's literature in science teaching: A possibility from a Study Situation]. (Monografia). Universidade Estadual de Santa Cruz-UESC, Ilhéus, Brasil. 
Jesus, D. (2016). O café nosso de cada dia: Investigação da influência de uma situação de estudo no processo de ensino aprendizagem de ciências da natureza no ensino médio [Our daily coffee: investigating the influence of a study situation on the process of teaching and learning nature sciences in high school]. (Dissertação). Universidade Estadual de Santa Cruz-UESC, Ilhéus, Brasil.

Pereira, D. B. (2017). Alimento e gastrite: Possíveis contribuições da Situação de Estudo para o PROEJA. [Food and gastritis: Possible Contributions from the Study Situation to the PROEJA]. (Monografia). Universidade Estadual de Santa Cruz-UESC, Ilhéus, Brasil.

Pimenta, S. S. (2016). Conhecendo a química dos cabelos cacheados: uma situação de estudo no curso técnico [Knowing chemistry's curly hair: A study situation in technical course]. (Monografia). Universidade Estadual de Santa Cruz-UESC, Ilhéus, Brasil.

Pinto, J. G. R. (2015). Situação de Estudo: Automedicação, um mal necessário? Uma abordagem curricular em um curso Técnico [Study Situation: Self-medication, necessary harm? A curricular approach in a Technical course]. (Monografia). Universidade Estadual de Santa Cruz-UESC, Ilhéus, Brasil.

Reis, C. M. R. (2016). Educação de Jovens e Adultos: A Situação de Estudo como possibilidade de repensar o currículo. (Monografia). [Youth and Adult Education: The Study Situation as a possibility to rethink the curriculum]. Universidade Estadual de Santa Cruz-UESC, Ilhéus, Brasil.

Resende, R. C. S. (2015). Desenvolvimento de Situação de Estudo como facilitadora do processo de ensino e aprendizagem de ciências da natureza no $9^{\circ}$ ano do ensino fundamental [Development of Study Situation as a facilitator of the process of teaching and learning nature sciences in the 9th grade of elementary school]. (Dissertação). UESC, Ilhéus, Brasil.

Sampaio, T. S. (2017). Educação de Jovens e Adultos: Atividade de formação continuada baseado nos pressupostos da Situação de Estudo. [Youth and Adult Education: A continuing education activity based on the assumptions of the Study Situation]. (Monografia). Universidade Estadual de Santa Cruz-UESC, Ilhéus, Brasil.

Santos, C. E. J. (2016). Possíveis contribuições da proposta curricular Situação de Estudo no currículo da educação de jovens e adultos. [Possible contributions of the curriculum proposal Study Situation in the Youth and Adult Education Curriculum]. (Monografia). Universidade Estadual de Santa Cruz-UESC, Ilhéus, Brasil.

Silva, F A. N. (2019). Situação de Estudo na formação de professores do MST: Diálogos com Henri A. Giroux. (Dissertação). [The Study Situation in MST Teacher Training: Dialogues with Henri A. Giroux]. Universidade Estadual de Santa Cruz-UESC, Ilhéus, Brasil. 
Silva, U. K. F. (2017). Rio Almada: Uma Situação de Estudo como proposta para o ensino de Química. [Almada River: A Study Situation as a Proposal for Science Teaching]. pp 51. Graduação em Licenciatura em Química. Universidade Estadual de Santa Cruz. Ilhéus, Bahia.

Sousa, P. S. (2018). Desenvolvimento profissional docente no contexto da reconfiguração curricular pela Situação de Estudo [Professional development of teachers in the context of curricular reconfiguration by the Study Situation]. (Dissertação). Universidade Estadual de Santa Cruz-UESC, Ilhéus, Brasil.

Vieira, L. B. G. (2017). Situação de Estudo: Compreensões dos formadores de professores do ensino de Ciências [Study Situation: Understandings of science teaching teacher trainers]. (Dissertação). Universidade Estadual de Santa Cruz-UESC, Ilhéus, Brasil.

Sara Souza Pimenta

https://orcid.org/0000-0002-9588-7243

Santa Cruz State University

Graduate Program in Science Education

Department of Exact Sciences and Technology

Ilhéus, Bahia, Brazil

pimenta.sara@outlook.com

Thiago Santos Guimarães

https://orcid.org/0000-0003-0709-5439

Santa Cruz State University

Graduate Program in Science and Mathematics Education

Department of Exact Sciences and Technology Ilhéus, Bahia, Brazil

thiago.s.guimaraes41@gmail.com

\section{Nataélia Alves da Silva}

https://orcid.org/0000-0002-2167-1255

Santa Cruz State University

Graduate Program in Science Education

Department of Exact Sciences and Technology

Ilhéus, Bahia, Brazil

natyalves_@hotmail.com 


\section{Andrei Steveen Moreno Rodríguez}

(ํ) https://orcid.org/0000-0002-3743-4633 Santa Cruz State University Graduate Program in Science and Mathematics Education Department of Exact Sciences and Technology Ilhéus, Bahia, Brazil wontola48@gmail.com

\section{Elisa Prestes Massena}

[1] https://orcid.org/0000-0002-7670-0201 Santa Cruz State University Graduate Program in Science and Mathematics Education Department of Exact Sciences and Technology Ilhéus, Bahia, Brazil elisapmassena@gmail.com

Submitted on 05th April 2020 Accepted on 08th September 2020 Published on 27th October 2020 